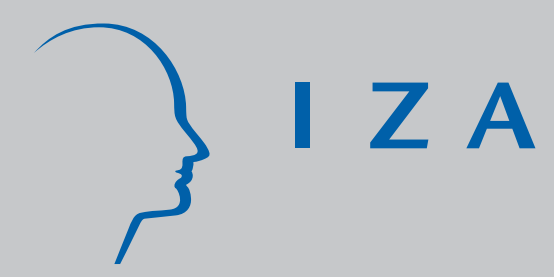

IZA DP No. 1473

Do Works Councils Inhibit Investment?

J ohn T. Addison

Thorsten Schank

Claus Schnabel

J oachim Wagner

J anuary 2005 


\title{
Do Works Councils Inhibit Investment?
}

\author{
John T. Addison \\ University of South Carolina, \\ Universidade de Coimbra/GEMF and IZA Bonn \\ Thorsten Schank \\ University of Erlangen-Nuremberg \\ Claus Schnabel \\ University of Erlangen-Nuremberg \\ Joachim Wagner \\ University of Lueneburg, \\ HWWA and IZA Bonn
}
Discussion Paper No. 1473
January 2005

\author{
IZA \\ P.O. Box 7240 \\ 53072 Bonn \\ Germany \\ Phone: +49-228-3894-0 \\ Fax: +49-228-3894-180 \\ Email: iza@iza.org
}

\begin{abstract}
Any opinions expressed here are those of the author(s) and not those of the institute. Research disseminated by IZA may include views on policy, but the institute itself takes no institutional policy positions.

The Institute for the Study of Labor (IZA) in Bonn is a local and virtual international research center and a place of communication between science, politics and business. IZA is an independent nonprofit company supported by Deutsche Post World Net. The center is associated with the University of Bonn and offers a stimulating research environment through its research networks, research support, and visitors and doctoral programs. IZA engages in (i) original and internationally competitive research in all fields of labor economics, (ii) development of policy concepts, and (iii) dissemination of research results and concepts to the interested public.
\end{abstract}

IZA Discussion Papers often represent preliminary work and are circulated to encourage discussion. Citation of such a paper should account for its provisional character. A revised version may be available directly from the author. 
IZA Discussion Paper No. 1473

January 2005

\section{ABSTRACT}

\section{Do Works Councils Inhibit Investment?}

Theory suggests that firms confront a hold-up problem in dealing with workplace unionism: unions will appropriate a portion of the quasi rents stemming from long-lived capital. As a result, firms may be expected to limit their exposure to rent seeking by reducing investments, among other things. Although there is some empirical support for this prediction in firm-level studies for the United States, we investigate whether this is also the case in the different institutional context of Germany where the works council is the analogue of workplace unionism. Using parametric and nonparametric methods and establishment panel data, we find no evidence that the formation (dissolution) of a works council has an unfavorable (favorable) impact on investment.

JEL Classification: J50

Keywords: $\quad$ works councils, investment, Germany

Corresponding author:

Joachim Wagner

Institute of Economics

University of Lueneburg

Campus 4.210

21332 Lueneburg

Germany

Email: wagner@uni-lueneburg.de 


\section{Introduction}

In the present paper, we investigate the impact of the German works council on investment. The works council is the counterpart of the workplace union in other countries, where considerable attention has focused on the hold-up question: the insight that unions may reduce and distort investments in physical capital if investors anticipate union rent seeking. Ultimately, this new theory has to be integrated within the corpus of traditional structural models of investment (on which, see Bond and Van Reenen, 2003). The relatively poor performance of neoclassical investment models obviously makes for caution in interpreting results from empirical applications involving union rent seeking, but should not hamstring empirical investigation of the hold-up problem. That problem has to be seen as (another) feature of the firm's environment that is important to understanding its investment behavior.

Further, analysis of the works council might throw important light on the subtheory because of the very different institutional framework in which the German entity is embedded. Although the works council has important codetermination powers at the workplace as well as extensive information and consultation rights, it cannot formally bargain over wages unless empowered to do so by the ruling collective agreement (negotiated at regional or industrial level by the relevant union and employer association). By the same token, the wide jurisdiction of the works council means that it has real bargaining power, and unsurprisingly wages have been shown to be higher in establishments with works councils (e.g. Addison, Schnabel, and Wagner, 2001; Hübler and Jirjahn, 2003). Nevertheless, the parent collective agreement, underwritten by the peace obligation (works councils cannot strike a plant), may help to limit rent seeking at the workplace. More creatively, participation in decision-making process through the aegis of the works council might encourage workers to take a longer run view of their companies. A partial decoupling of the issues of wealth creation and its distribution in the German case can translate into an attenuation of the hold-up problem.

There is a growing literature on the effects of works councils on various aspects of firm performance (for a survey, see Addison, Schnabel, and Wagner, 2004). But there has been almost no investigation of the works council-investment nexus, which relation is 
fundamental to the performance question. Moreover, there is the unsettled issue of unobserved plant heterogeneity. Most studies have examined the effect of works council presence on the outcome indicators without considering the stable but unobserved characteristics of the firm that may be associated with performance and the frequency of the works council institution. This omission may be of particular importance in the case of investment, leading us to provide within-plant estimates of works council impact. Using changes in works council status gives us more confidence in drawing inferences as to causality. ${ }^{1}$

The paper proceeds as follows. In section II we briefly outline the hold-up model. Although the theory is ultimately ambiguous, the empirical evidence on the association between worker representation and investments in physical capital, reviewed in section III, points fairly consistently to lower investments in the presence of unions and, in one study, German works councils. In section IV we introduce our nationally representative dataset. Section V contains the results of our empirical inquiry, providing investment function estimates as well as an alternative matching approach to determining the impact of works councils on investment. These parametric and nonparametric methodologies yield findings that differ sharply from the Anglo-Saxon experience. In section VI we interpret our results and draw some conclusions.

\section{Theory}

Theoretical considerations suggest that unions can have positive as well as negative effects on investment. In the traditional model, the union-set wage is represented as an exogenous change in the price of labor, and the firm adjusts employment along the labor demand curve. In this case, the union premium or tax is levied on labor. Union firms substitute away from expensive labor, but the net effect on investment is unclear: it depends on the degree of substitutability between capital and labor and the magnitude of the scale effect as the premium filters through into higher product prices and output falls.

By contrast, the modern view is that unions tax capital, that firms respond unambiguously by cutting investment, and that the wage is endogenous. The idea is that unions expropriate part of the quasi-rents that form part of the normal (i.e. competitive) 
returns to capital but which are vulnerable to capture once investment in specialized plant and equipment has been made. Familiarly, such assets will continue in use as long they earn a return above their alternative use; the more specific the asset, the bigger the scope for union rent seeking. Of course, with the relation-specific capital in situ, higher wages are unlikely to influence the use of the asset, but firms will anticipate reduced returns to such capital and invest less.

This is the so-called 'hold-up' problem, first carefully analyzed by Grout (1984). Consider a simple one shot two-stage game. In the first stage, the firm chooses a level of capital (high/low) and in the next the union chooses the wage (high/low). By backwards induction, the union will always choose a high wage at stage two and, knowing this, the firm will always choose a low investment strategy at stage one. As noted, the union tax on investment will vary directly with the specificity of the asset and its longevity. The tax would vanish were the union able to commit itself to a low wage strategy by posting a bond or hostage to a third party, or where there was bargaining over investment as well as wages. However, neither arrangement is other than sporadically encountered in the real world. $^{2}$

Collective bargaining is of course repeated over time rather than being a one-shot exercise and, abstracting from an end-game scenario, repeated games offer a solution to the hold-up problem since opportunistic behavior can in principle be appropriately punished (e.g. van der Ploeg, 1987). An important issue in the literature has been the degree to which unions discount the future. In particular, it has been argued that because union members do not have property rights in the union they will be rationally myopic and discount the future at a higher rate than shareholders. And this tendency will be reinforced by the greater influence of older workers in union councils (Hirsch and Prasad, 1995). Accordingly, much hinges in a repeated game context on the union's discount factor and the success of firms in extending the union's horizon (including greater recourse to debt), as well as inefficient defensive strategies such as the maintenance of inefficient capital or plants to facilitate substantial cuts in employment as a short-run profit-maximizing response to wage demands (for a discussion, see Baldwin, 1983). 
There is a strong presumption in the unions-and-investment literature, therefore, that greater worker representation will depress investments in physical and intangible capital - the Grout result - and lead to greater reliance on debt financing. However, two theoretical caveats and a qualification are in order. First, Addison and Chilton (1998) have shown that union opportunism alone does not necessarily underpin suboptimal investments in physical capital and that - irrespective of the union's horizon or the productive life of capital - sufficient patience on the part of the firm can yield selfenforcing contracts that are efficient with respect to employment and investment. In other words, the efficient outcome may depend crucially on the firm's discount factor. Second, uncritical extension of the hold-up model to investments in intangible capital (i.e. R\&D) should be resisted. As noted by Menezes-Filho and Van Reenen (2003, p. 299), the tendency toward strategic R\&D "undermines the analytical clarity of the Grout result." Specifically, in circumstances of a patent race in $R \& D$, an increase in union power can increase employment and market share and in turn lead to increased $\mathrm{R} \& \mathrm{D}$ to preserve market share.

As for the qualification, it is simply that the agency of worker representation considered in the present treatment is the German works council rather than the trade union to which the theory refers - and the Anglo-Saxon union on which the empirical literature focuses. As noted earlier, the works council is embedded in a dual system of industrial relations wherein its wage bargaining role is circumscribed to a greater or lesser extent by the sectoral collective bargaining agreements negotiated by the unions. While works councils are not allowed to bargain over wages unless expressly authorized by the relevant sectoral agreement, their extensive rights of information, consultation and codetermination in many other issues mean that works councils have a strong influence which can be used for rent-seeking and which often results in higher effective wages paid (see Addison, Schnabel, and Wagner, 2001). On the other hand, the dual system of industrial relations in Germany may mean that there is sufficient divorce of distributive from production issues for the works council to focus on the latter, especially in circumstances where its own powers - and in particular those of codetermination or joint decision-making - encourage the work force to take a longer-term view of the enterprise. 


\section{Literature Review}

A review of the extant empirical literature at firm/establishment level is provided in Table 1. Although most of the studies in the table tackle more outcome indicators than investments in physical capital alone, we shall focus our narrative on the results for tangible capital and simply note some wider results (most notably on profits) as necessary.

(Table 1 near here)

The study by Hirsch (1991) in row 1 of the table sets the standard for the rest. It derives by survey its own measure of union presence, applies the distinction between the direct effects of unionism and the indirect effects stemming from the wage premium - the latter necessitating the estimation of an auxiliary profits equation - and identifies nonlinearities in union effects. It also tests the robustness of its principal results, and looks to supportive findings for other investment outcomes and other indicators suggested by the theory (e.g. higher debt-equity ratios). Hirsch reports solid evidence of the distortionary long-run effects of union rent seeking: union companies invest around 20 percent less in plant and equipment than do similar nonunion companies (see also Hirsch, 1992).

The next two studies in the table are illustrative of the difficulty confronted by analysts in obtaining firm-based measures of unionism. Bronars and Deere (1993) fashion their density indicator from industry-level values from the CPS. They obtain somewhat weaker results than Hirsch for investment in tangible capital (but stronger results for some other indicators such as R\&D and debt-equity ratios). The sensitivity of matching industry unionization rates to individual firm data is explicitly tackled in the study by Bronars, Deere, and Tracy (1994). The authors compare a measure of firm-level unionism derived from BLS contract information with CPS data to gauge the adequacy of the latter 'matching' measures, using coverage data from Hirsch's (1991) survey to obtain an estimate of the measurement error in the former estimate. Although their focus is on measurement issues, they again find that higher union coverage is associated with lower investment in plant and equipment. But the direct effects of unionism are poorly 
determined in this treatment (at least for physical investment, if not for the other outcomes investigated.)

The study in row 4 of the table is of interest because it seeks to test the argument that unions reduce asset-specific investments, as underpins the bargaining problem emphasized in the theory. Assuming that asset specificity is directly associated with investment (as well as with excess market value and employment growth), Cavanaugh (1998) looks to the union effect on investment being amplified by asset specificity and hence includes an interaction term between the two variables in his investment equation. As can be seen, he obtains strongly negative coefficient estimates for both the union measure and the interaction term. He also reports adverse union effects on the other outcome indicators examined (firm profitability and employment growth).

Only one of the firm studies in the table is able to exploit a time series for unionization. In an approach that has found favor in the profits literature, Fallick and Hassett (1999) consider the effects of union representation elections on firm performance over a sample period of more than two decades. For their 'surprises' model they consistently report evidence of materially lower investment in the wake of union wins. By way of underscoring the magnitude of the union tax they compute that its effect is equivalent to a 33 percentage point hike (from .34 to .67 ) in the corporation tax.

The last two entries in the table are the only non-U.S. studies. Addison, Kraft and Wagner (1993) consider the impact of the German works council on capital investment, the subject of our larger inquiry. They find that gross investment is between one-fifth and one-third lower in a works council plant than in its counterpart without the institution, which at first blush suggests that the effects of workplace representation in Germany seem no less severe than in the United States. However, the study is based on a small sample of likely unrepresentative plants, and the authors duly note the fragility of their investment equations. Using a much larger sample, Hübler (2003) estimates that works council presence is associated with higher levels of expansion investment, ICT investment, and other investment in medium-sized German establishments. Using a threeequation model, this positive overall effect is found to stem exclusively from the indirect 
effects of works councils operating through reorganization and training. On the other hand, the direct effect of works councils on investment is negative albeit statistically insignificant (see also the companion study by Gerlach, Hübler, and Meyer, 2002, where this inverse association is statistically significant in one specification). It should be noted, however, that the studies in rows 6 and 7 of the table rely on single cross sections of data and only make use of information on works council presence (rather than changes in works council status), so that any attribution of causality is difficult.

Statistical limitations notwithstanding, the firm- and plant-level studies point nearly universally to reduced investment in tangible capital under unionism. ${ }^{3}$ Interestingly, the same holds true of the handful of industry-level studies, not summarized in our table. Indeed, for a sample of 18 Canadian industries, 1967-87, Odgers and Betts (1997) estimate that were an industry with zero union representation to attain the sample average union density of 44 percent, its gross (net) investment rate would be reduced in the range 66 to 74 (18 to 25 ) percent relative to the status quo ante. As do several of the firm studies, the authors test for (and detect) a nonlinear association between the union measure and investment, although unlike those studies the indirect union effect on investment operating through reduced profitability is economically insignificant.

Another industry-level study, this time for Britain, again reports strongly negative effects of unions on investment. In an analysis of two datasets using first differences and panel methods, and distinguishing between union recognition and union density, Denny and Nickell (1992) report that a firm with a recognized union and an average level of union density would have an investment rate some 28 percent lower than an equivalent firm with no unions, cet par. ${ }^{4}$ Adding in the indirect effects of unions - in the model, the wage effect is positive and the productivity effect negative - this estimate is reduced to a still very substantial 16 percent (in the competitive sector).

Aggregation problems ensure that we should focus on the firm in investigating union impact on investment, ${ }^{5}$ but one potentially interesting result contained in Denny and Nickell (1992, p. 882, fn. 9) is their finding of a positive influence of joint consultative committees - joint meetings of employers and managers concerned with 
consultation rather than negotiation - on investments in plant and machinery. Given that this body is akin to the German institution, might not the works council be sufficiently concertative and removed from negotiation to even have a positive influence on investment?

\section{Data}

Our data are taken from the IAB Establishment Panel of the Institute for Employment Research of the Federal Labor Agency. Each year since 1993 (1996), this panel has surveyed several thousand establishments from all sectors of the economy in Western (Eastern) Germany. It is based on a stratified random sample - strata for 16 industries and 10 size classes - from the population of all establishments with at least one employee covered by social insurance. To correct for panel mortality, exits, and newly-founded units, the data are augmented regularly, yielding an unbalanced panel. Participation of establishments is voluntary, but the response rates (which exceed 70 percent) are high compared with other non-official German firm panel studies. The first wave of the IAB panel (1993) included 4,265 West German plants; and in 1996, the East German establishment panel started with 4,313 plants. Overall, the IAB panel has increased in size every year - and as of 2003 covers approximately 16,000 establishments - to facilitate regional analysis at the level of federal states.

Data are collected in personal interviews with the owners or senior managers of the establishments by professional interviewers. The panel is created to serve the needs of the Federal Labor Agency, and so its focus is on employment-related matters. Note that the IAB panel is the only nationally representative longitudinal sample of establishments in Germany that can be used to investigate works council impact. Details of the IAB panel (including information on the questionnaire(s) and how to access the data) are given in Kölling (2000).

In investigating the impact of works councils on investment, our study uses information on the presence (or otherwise) of a works council in a plant during the interval 1998 to $2003 .{ }^{6}$ The relevant question was posed to all establishments in 1998, 2000, 2002 and $2003 .^{7}$ The crucial information is the course of a plant's works council 
status through time, which allows us to identify the impact of a works council on investment through within-plant changes in the presence of a works council rather than relying on between-plant comparisons. Therefore, we categorize plants into four different groups. First, there are plants which never had a works council across all years for which information is available. The second group comprises plants that did not have a works council in 1998, but subsequently reported that they had one in 2000 which was still operational in 2002 and 2003. The third group is made up of plants that always had a works council. Finally, the fourth group consists of establishments in which the works council was dissolved (i.e. plants that reported the existence of a works council in 1998 but not in 2000 until 2003). All plants changing their works council status after 2000 were excluded from the analysis. Our focus, then, is upon the impact of a regime shift (the setting up or abandonment of a works council) occurring between 1998 and 2000 on investment in the following years (2000 to 2002).

The dependent variable in our analyses is average investment divided by sales in the period 2000 to $2002 .^{8}$ We are able to use data on total investment as well as information on (the share of that investment that is) 'expansion investment' as opposed to replacement investment. Because sales are measured differently for establishments from the banking and insurance sectors and for public sector establishments, these industries have to be excluded from the analysis. Furthermore, the usable sample shrinks considerably due to attrition or missing values but, depending on the estimation strategy pursued, there are still several hundred to several thousand plants that can be observed.

\section{Findings}

In our empirical analysis we make use of three alternative estimation strategies to ascertain how a works council affects investment. In each case, we investigate whether the setting up (dissolution) of a works council between 1998 and 2000 inhibits (increases) investment between 2000 and 2002. This is achieved by comparing the investment behavior of plants setting up (abandoning) a works council with those of establishments that never (always) had a works council. Each approach is carried out separately for total investment and for expansion investment. 


\section{Estimating Investment Functions}

In the first two approaches we estimate a reduced form investment function that employs the standard covariates used in the literature, in so far as these are available in our data set. ${ }^{9}$ Our first explanatory variable is an establishment's growth in sales between 2000 and 2002, since a rising demand for goods and services may only be satisfied through an increase in the capital stock, via expansion investment. The economic performance of an establishment is also expected to have a positive impact on investment: the better the profit situation, the higher the expected return on investment, and the more plentiful the financial resources available for investment. Therefore, a dummy variable indicating whether or not the profit situation in 1999 was either very good or good is utilised here. Although we have normalized the investment measure by total sales, we include establishment size as a further independent variable. According to Schumpeterian arguments, there should exist a positive relationship between a firm's size and its innovation as well as investment behavior. In addition, investment per unit of sales may be greater in large firms due to their easier access to financial markets and greater willingness to accept risk. We use both the number of employees and its square to pick up any non-linearity in the relationship between establishment size and the investment ratio. We also deploy two dummy variables reflecting formal collective bargaining arrangements: whether or not the establishment has concluded a collective agreement (either through the employers association at sectoral level or with the union directly at firm level) and is thus subject to union wages. In both cases, investment might be higher if firms substitute away from expensive labor; but if collective bargaining takes place at firm level, the firm also faces an increased risk of rent capture, thereby inhibiting investment. Next, as a crude representation of the dynamic adjustment of the capital stock, we include the lagged dependent variable; specifically, the average of investment divided by total sales over the three years 1997-99. Finally, we deploy ten industry dummies to capture sectoral differences in investment behavior (possibly due to different positions in the business cycle), and also enter a dummy for Eastern Germany. Although the economic situation remains worse in post-communist Eastern Germany which should therefore serve to depress investment, by the same token the heavy subsidization of capital in the east should act as spur to investment. 
Our main focus is of course on the three dummy variables representing the various works council regimes; that is, whether a works council was set up, dissolved, or always in existence. (Establishments that never had a works council form the reference group.) A significant negative coefficient estimate in respect of works council formation, for example, would imply that these plants invest less than do their counterparts that remained free of work councils. It is also of interest to determine whether the effect of works council dissolution significantly differs from that continuous works council presence, and whether plants that have recently abandoned a works council behave similarly to those that never had one.

OLS results for our reduced form investment equation allowing for separate intercepts in the case of each works council regime are presented in Table $2 .{ }^{10}$ It can be seen that the coefficient estimates for most of our control variables have the expected signs and are statistically significant at the 10 percent level or better. Sales growth, a good profit situation of the plant, and a plant's location in Eastern Germany are all associated with higher investment, whereas establishment size and the existence of collective agreement do not seem to play a role. Average investment between 1997 and 1999 makes a large contribution to the explained variation of investment between 2000 and 2002, and the relationship is stronger for total investment. This seems plausible since total investment is composed of expansion investment and replacement investment, and the latter - reflecting the depreciation of the capital stock - should evince stronger autocorrelation through time.

(Table 2 near here)

Focusing on our works council dummies, we see that establishments that always had a works council record significantly higher investment than reference group plants. This difference in levels should, however, not be overemphasized. Although this relation may reflect plants' reactions to higher labor costs associated with permanent works council presence (as found by Addison, Schnabel and Wagner, 2001), it also could indicate that both groups of plants are so different in many respects that we have nonoverlapping distributions of the covariates (see below). More interesting, and more 
important for a causal interpretation of works council effects, are the point estimates of the dummies indicating a change in works council status. We see that the coefficient estimate for the dummy indicating the formation of a works council is altogether insignificant for both total and expansion investment. Similarly, plants that had abandoned their works council do not record higher investment than those plants in which a works council continued in operation. Neither result favors the hypothesis that works councils inhibit investment. By way of caution, however, we note that our results are based on only a small number of changers: the regression sample includes 1,309 (660) plants that never (always) had a works council, but only 19 (26) reporting the formation (abandonment) of a works council.

The preceding estimation strategy attributes any changes in investment behavior between the four different works council regimes to intercept shifts, thereby assuming that the other covariates have the same impact throughout. This restriction is relaxed in our second approach in which our investment equations only use data pertaining to plants that did not experience a change in works council status (i.e. we fit separate investment equations to data from plants that either never had or always had a works council). The estimated coefficients are then used to predict investment in plants that changed their works council status. More precisely, the estimated parameters from the regression containing plants that never (always) had a works council are used to simulate the hypothetical investment behavior of plants that set up (abandoned) a works council had they not changed regime. Assuming that the unobserved factors are uncorrelated with works council presence, any difference between the average predicted value and the actual value of investment in plants setting up or abandoning a works council is due to different parameters in the investment function of the groups of plants that changed or did not change their works council status. This could be due to an intercept shift or due to different impacts of the other covariates, both of which elements may be regarded as the effect of a works council formation (abandonment) on investment.

(Tables 3 and 4 near here) 
The results of estimating our investment equation separately for establishments that either never had or always had a works council are given in Table 3 . They are more or less in line with the results in Table 2. That said, it can be seen that the explained variation of investment is much higher for those plants that always had a works council. (Such plants are considerably larger on average; see Table 5 below.)

Using the estimated parameters from these regressions, we can predict investment (normalized by sales) for those plants which have set up (abandoned) a works council and compare these values with the actual investment of the respective groups. If works councils do indeed inhibit investment, we would expect to observe a lower (greater) actual than predicted value for plants setting up (abandoning) a works council. Table 4 shows that the difference between predicted and actual investment is not significantly different from zero for plants that have set up a works council. Actual total investment is even significantly smaller than the predicted value for plants abandoning a works council, although the difference in expansion investment is insignificant. By way of summary, our second estimation strategy reconfirms the findings of the first approach and does not indicate any evidence of a negative impact of works councils on investment.

\section{A Matching Approach}

The above approaches employ OLS methods that are based on the assumption of a linear relationship between the dependent variable and the covariates. Relatedly, OLS does not take into account the possibility of a non-common support (i.e. a non-common range of values of the covariates) between plants that set up (abandoned) a works council and plants in which works councils were never (always) present. This can result in extrapolating outside the common support when using parametric techniques. Therefore, in our third strategy we employ the matching method, which is a nonparametric (or semiparametric) approach to identify the impact of a specific treatment on certain outcomes and which allows a causal interpretation of treatment effects. ${ }^{11}$

In our case, the treatment is the formation of a works council between 1998 and 2000 , and the outcome is average investment divided by total sales in the succeeding years. ${ }^{12}$ The (average) treatment effect is identified by choosing a subset of the control 
group of untreated plants (those plants that never had a works council) having observable characteristics in 1998 as similar as possible to the treated group (those plants setting up a works council after 1998). Conditioning on the observables, the method assumes that the only remaining difference between the two groups of plants is the treatment status. Accordingly, the average impact of the treatment can be recovered through a comparison of the investment means of both groups. The matching analysis avoids the two problems mentioned earlier. First, it does not rely on a linear relationship in the investment equation. Second, the analysis is restricted to the region of common support; consequently, the estimated treatment effect is only valid for the region where both data on the treated plants as well as data from the control group is observed. ${ }^{13}$

In our particular context, the identifying assumption when using matching methods (i.e. the conditional independence assumption) is that plants setting up a works council would have displayed the same investment behavior as the control group in the (hypothetical) case that they had not done so. To satisfy this condition, we must take into account all variables that are expected to exert an influence on the decision to set up a works council and on investment.

We apply propensity score matching, wherein the selection of the control group is carried out on the basis of the probability that a unit has received treatment, conditional on the observed variables. The propensity score is obtained from a probit regression of a dummy variable indicating whether or not a works council was formed between 1998 and 2000 on a vector of covariates consisting of the following arguments: the number of employees (and the squared number of employees); the percentages of part-time employees, of female employees, and of blue-collar workers; dummy variables for collective agreements concluded at either of two levels (sectoral or firm); dummy variables denoting branch-plant status, the profit situation, and the legal form of the enterprise; and dummies for the age of the establishment (formed within the last five years, or earlier), the region (Western vs. Eastern Germany), and industry affiliation. ${ }^{14}$ We then stratified the data by sector and region (Eastern versus Western Germany). For each establishment in which a works council was set up, the most similar unit (in terms of its propensity score) among those plants in the same cell that never had a works council 
was selected (so-called nearest neighbour or one-to-one matching). Then, the mean investment of the treated establishments was compared with the mean of the matched non-treated establishments.

(Table 5 near here)

As mentioned above, the parametric strategies used earlier do not take into account that the distributions of treated and untreated plants may not sufficiently overlap. In fact, there are some marked differences within the two pairs of works council regimes in 1998 (i.e. before a works council was set up or abandoned). Table 5 examines these differences for several workplace characteristics that have been found to be associated with works council presence. ${ }^{15}$ Thus, for example, it can be seen that establishments abandoning their works councils between 1998 and 2000 had on average fewer employees than those plants that always had a works council. In addition, establishments abandoning a works council were less likely to be branch plants, to be located in Western Germany, to apply a bargaining agreement, and to report a good or very good profit situation compared with plants which always had a works council. Comparing plants that set up a works council with those that never had one, it appears that the former group are more likely to be branch plants, to be located in Western Germany, to be a family-owned firm, to report good profits, and to apply a sectoral-level bargaining agreement than plants that never had a works council.

These differences are eliminated in the matching approach, to which we next turn. To repeat, for each treated plant we search in the same region (West versus East) and in the same sector (from a total of nine) for the most similar plant in terms of the propensity score (obtained from the probit regression) in the control group. ${ }^{16}$ Note that in this process each matched establishment from the control group is never used more than once to form a statistical twin (one-to-one matching), so that the results reported below are based on totally different pairs of treated and non-treated plants. The matched non-treated establishments form the new control group.

(Table 6 near here) 
Table 6 indicates that the matching was successful. A comparison of the mean values of variables in 1998 for the two pairs of treated and control plants (works council formation versus 'never present,' and works council abandonment versus 'always present') shows no statistically significant differences at conventional levels. ${ }^{17}$ In other words, the respective treated and control groups are very similar. However, the sample of plants setting up a works council is now only 25 , while that identified as abandoning a works council falls to $21 .^{18}$ This reduction occurs because no comparable twin (in the same sector and region) could be found for the plants that dropped out of the analysis. More technically, the propensity score of the treated unit was outside the estimated propensity score distribution of the untreated plants.

(Table 7 near here)

Mean values of our two investment outcome variables for the respective planttypes are reported in Table 7. All probability values imply that the observed differences between the treated and untreated groups are statistically insignificant. Again, we do not find evidence that either setting up a works council inhibits investment in subsequent years or abandoning a works council increases future investment. This result is consistent across all three approaches applied and casts doubt on the validity of the unions-reduceinvestment hypothesis as it applies in a German context.

\section{Conclusions}

Using establishment panel data, we have applied three alternative estimation strategies involving parametric and nonparametric methods - in order to determine the impact if any of works councils on investments in tangible capital. We can find no evidence that the formation (dissolution) of a works council has an unfavorable (beneficial) effect on investment. Nor for that matter do we find that changes in work council status have a positive effect on the investment bottom line. These are important results that fill a hole in the developing German literature on the effects of works councils on firm performance. They are also important more generally in addressing the hold-up problem, and in pointing to institutional arrangements that might attenuate that problem (see Freeman and Lazear, 1995). 
That said, our results have to be interpreted with some care. There is first the issue of the small number of plants recording a change in works council regime over the sample period, making it difficult to detect statistically significant differences in investment behavior. Then there is the question of the model. The insignificant overall impact of works councils on investment might in practice reflect opposing effects of works councils on investment, with capital-labor substitution being offset by opposing effects on capital formation stemming from rent seeking.

Finally, there is the issue of perception. Despite our findings, and some potentially corroboratory evidence on investments in intangible capital (e.g. Schnabel and Wagner, 1994; Addison, Schnabel, and Wagner, 2001; Kraft and Stank, 2004), both anecdotal evidence and surveys of businessmen indicate that international investors are seemingly reluctant to invest in Germany because of that country's (little understood) system of codetermination. If this is the case, if codetermination does put off foreign investment, then works councils may indeed reduce investment in a way that our methodology cannot handle. That said, we suspect that the perceptions have more to do with codetermination at the enterprise level (where unions and employees can get half of the seats on the supervisory board) than with the codetermination at the establishment level investigated here.

\section{Endnotes}

1. As we will be exploiting changes in works council status, it should be noted that works councils are mandatory in all plants with five or more permanent employees. They are not automatic, however, and for a works councils to be elected just three employees with voting rights (i.e. aged at least 18 years) must first call for an electoral board to be convened. Once this procedure has been set in motion, the establishment of a works council is a fait accompli, with the electoral board holding the election. By the same token, works councils can equally easily lapse. This will occur if no re-election takes place, or if works councilors cease actively to meet or otherwise quit the plant. The entity can therefore be set up or dissolved at any point in time by the plant's employees. Nevertheless, we shall see that either event is rather rare.

2. There is also a potential hold-up problem on the other side of the employment relation. The usual example given is employer capture of the quasi rents accruing to workers from their co-investments in firm-specific human capital (Metcalf, 2003), which problem is commonly 'elided' by noting that the firm is longer lived than the employment relation and that its owners (unlike union members) have marketable property rights. Future cash flows will be prejudiced by the consequences for wage cost of a damaged reputation. But 
there is also an example in investment and employment determination. In their extension of the Espinoza and Rhee (1989) model, Addison and Chilton (1998) argue that the ability of the union to punish the firm for opportunistic behavior (specifically, cheating on employment) may actually be increased in circumstances of finite capital durability. However, for a firm discount factor close to 1 , it will not pay the employer to cheat.

3. We note parenthetically that the only studies pointing to insignificant or positive union effects on investment do not have data on actual investments; see respectively, Machin and Wadhwani (1991) and Benson (1994).

4. The authors rationalize the positive coefficient estimate for union density on the grounds that, if there is a union and new capital is being installed, it pays management not "having to make separate arrangements for a substantial body of non-union workers" (Denny and Nickell, 1992, p. 882).

5. But note that firm-level analysis may understate the overall impact of unionization on investment where threat effects apply. If nonunion firms respond by raising wages to preempt the unionization of their employees, then their investment may fall as well.

6. Although employees in all establishments with five or more permanent employees can elect a works council, only one in six establishments in the private and public sector had a works council in 2000 (for details, see Addison et al., 2003).

7. In the missing years, the question was only asked of panel accessions, which perforce cannot be used in our longitudinal analysis.

8. We have divided investment by total sales in order to avoid scale effects. Information on both total sales and investment in year $t$ is asked for in the survey conducted in the following year. If there were missing values for investment or sales in any of the three years, we calculated the average using information from the remaining two years. In the event that we had usable information on establishment investment (divided by total sales) for just one year, the plant was dropped from the sample.

9. For extended discussions of theoretical and empirical investment equations, see Jorgensen (1963), Hirsch (1991), and Bond and Van Reenen (2003). We do not have information on the price of capital or on the investment and/or financial constraints confronted by individual firms, although some of the determining factors here may in part be indirectly captured by certain of our other explanatory variables such as firm size and industry affiliation. Further, because our econometric specifications are not explicitly derived from optimal investment behavior, given some specified structure of adjustment costs, the reduced form models used here only "represent an empirical approximation to some complex underlying process that has generated the data" (Bond and Van Reenen, 2003, p. 34). Recent investment studies using German firm-level data include Neubäumer and Kohaut (2002), Bond, Harhoff, and Van Reenen (2003), and Kirchesch (2004). 
10. All computations were performed at the Institute for Employment Research of the Federal Labor Agency, using Stata/SE 8.2. To facilitate replication and extensions, the do-files are available from thorsten.schank@wiso.uni-erlangen.de.

11. Matching analysis and the causal interpretation of the effects identified can be traced back to Rubin (1974). Latterly, the approach has become very popular in the evaluation of labor market programs; see, for example, Heckman, LaLonde, and Smith (1999).

12. Analogously, we also investigate the treatment effect of abandoning the works council, where the control group now consists of all those plants which always had a works council. Due to space constraints, we will only refer to the formation of a works council as a treatment.

13. Note that both regression and matching analysis require the decision to set up a works council, conditional on the covariates, to be independent of the unobservables.

14. For an econometric analysis of the determinants of works council presence and their introduction that is also based on the IAB panel and makes use of these covariates, see Addison et al. (2003).

15. Note that the number of observations now exceeds those reported in Tables 1 through 3 , because of missing values for the lagged dependent variables and sales growth in the investment equations.

16. Matching was performed in Stata 8.2 using the PSMATCH 2 command (Leuven and Sianesi, 2003).

17. The sole exception being establishment formation during the last five years, which is now more likely (and statistically significant at the .05 level) for plants that always had a works council than for those plants that abandoned their works councils between 1998 and 2000 .

18. For expansion investment, the number of comparable plants is 24 (setting up vs. never present) and 20 (abandoning vs. always present), respectively. 


\section{References}

Abowd, John. "The Effects of Differential Unionization Environments on the Pattern of Interindustry Investment.” Mimeograph, Cornell University, 1989.

Addison, John T., Lutz Bellmann, Claus Schnabel, and Joachim Wagner. "German Works Councils Old and New: Incidence, Coverage and Determinants", Schmollers Jahrbuch 123 (2003): 339-358.

Addison, John T. and John Chilton. "Self-Enforcing Union Contracts: Efficient Investment and Employment." Journal of Business 71 (July 1998): 349-369.

Addison, John T., Claus Schnabel, and Joachim Wagner. "Works Councils in Germany: Their Effects on Establishment Performance". Oxford Economic Papers 53 (October 2001): 659-694.

Addison, John T., Claus Schnabel, and Joachim Wagner. "The Course of Research into the Economic Consequences of German Works Councils." British Journal of Industrial Relations 42 (June 2004): 255-281.

Addison, John T., Kornelius Kraft, and Joachim Wagner. "German Works Councils and Firm Behavior." In Bruce E. Kaufman and Morris M. Kleiner, eds., Employee Representation: Alternatives and Future Directions. Madison, WI: Industrial Relations Research Association, 1993, pp. 305-338.

Baldwin, Carliss Y. "Productivity and Labor Unions: An Application of the Theory of Self-Enforcing Contracts.” Journal of Business 56 (April 1983): 155-185.

Benson, John. "The Economic Effects of Unionism on Japanese Manufacturing Enterprises.” British Journal of Industrial Relations 32 (March 1994): 1-21.

Bond, Stephen, Dietmar Harhoff, and John Van Reenen. "Investment, R\&D and Financial Constraints in Britain and Germany." CEP Discussion Paper No. 595, London School of Economics, December 2003.

Bond, Stephen and John Van Reenen. "Microeconometric Models of Investment and Employment". Mimeograph, Nuffield College, Oxford, 2003.

Bronars, Stephen G. and Donald R. Deere. "Unionization, Incomplete Contracting, and Capital Investment." Journal of Business 66 (January 1993): 117-132.

Bronars, Stephen G., Donald R. Deere, and Joseph S. Tracy. "The Effects of Unions on Firm Behavior: An Empirical Analysis Using Firm-Level Data." Industrial Relations 33 (October 1994): 426-451. 
Cavanaugh, Joseph K. “Asset Specific Investment and Unionized Labor.” Industrial Relations 37 (January 1998): 35-50.

Connolly, Robert A., Barry T. Hirsch, and Mark Hirshey. "Union Rent Seeking, Intangible Capital, and Market Value of the Firm." Review of Economics and Statistics 68 (November 1986): 567-577.

Denny, Kevin and Stephen J. Nickell. "Unions and Investment in British Industry." Economic Journal 102 (July 1992): 874-887.

Espinoza, M.P. and C. Rhee. "Efficient Wage Bargaining as a Repeated Game." Quarterly Journal of Economics 104 (August 1989): 565-568.

Fallick, Bruce C. and Kevin A. Hassett. "Investment and Union Certification." Journal of Labor Economics 17 (July 1999): 570-582.

Gerlach, Knut, Olaf Hübler, and Wolfgang Meyer. "Investitionen, Weiterbildung und betriebliche Reorganisation." Mitteilungen aus der Arbeitsmarkt- und Berufsforschung 35 (2002): 546-565.

Grout, Paul A. "Investment and Wages in the Absence of Binding Contracts: A Nash Bargaining Approach." Econometrica 46 (March 1984): 449-460.

Heckman, James, Robert LaLonde, and Jeffrey Smith. "The Economics and Econometrics of Active Labor Market Programs," in Orley C. Ashenfelter and David Card, eds., Handbook of Labor Economics, Volume 3A. Amsterdam: North-Holland, 1999, pp. 1865-2097.

Hirsch, Barry T. Labor Unions and the Economic Performance of Firms. Kalamazoo, MI: W.E. Upjohn Institute for employment Research, 1991.

Hirsch, Barry T. Firm Investment Behavior and Collective Bargaining Strategy." Industrial Relations 31 (Winter 1992): 95-121.

Hirsch, Barry T. and Kislaya Prasad. "Wage-Employment Determination and a Union Tax on Capital: Can Theory and Evidence Be Reconciled?" Economics Letters 48 (April 1995): 61-71.

Hübler, Olaf. "Zum Einfluss des Betriebsrates in mittelgroßen Unternehmen auf Investitionen, Löhne, Produktivität und Renten - Empirische Befunde," in Nils Goldschmidt, ed., WunderbareWirtschaftsWelt - Die New Economy und ihre Herausforderungen. Baden-Baden: Nomos, 2003, pp. 77-94.

Hübler, Olaf and Uwe Jirjahn. "Works Councils and Collective Bargaining in Germany: The Impact on Productivity and Wages." Scottish Journal of Political Economy 50 (September 2003): 471-491. 
Jorgenson, Dale. "Capital Theory and Investment Behavior." American Economic Review, Papers and Proceedings 53 (May 1963): 247-259.

Kirchesch, Kai. "Financial Risks, Bankruptcy Probabilities, and the Investment Behaviour of Enterprises". HWWA Discussion Paper No. 299, Hamburg, October 2004.

Kölling, Arnd. “The IAB-Establishment Panel.” Schmollers Jahrbuch 120 (2000): 291300.

Kraft, Kornelius and Jörg Stank. "Die Auswirkungen der gesetzlichen Mitbestimmung auf die Innovationsaktivitäten deutscher Unternehmen." Schmollers Jahrbuch 124 (2004): 421-449."

Leuven, Edwin and Barbara Sianesi. "PSMATCH2: Stata Module to Perform Full Mahalanobis and Propensity Score Matching, Common Support Graphing, and Covariate Imbalance Testing." Statistical Software Components S432001, Boston College Department of Economics, 2003.

Machin, Stephen and Sushil Wadhwani. "The Effects of Unions on Investment and Innovation - Evidence from WIRS.” Economic Journal 101 (March 1991): 324-330.

Menezes-Filho, Naercio and John Van Reenen. "Unions and Innovation: A Survey of the Theory and Empirical Evidence," in John T. Addison and Claus Schnabel, eds., International Handbook of Trade Unions. Cheltenham, England, and Northampton, MA: Edward Elgar, 2003, pp. 293-334.

Metcalf, David. "Unions and Productivity, Financial Performance and Investment: International Evidence," in John T. Addison and Claus Schnabel, eds., International Handbook of Trade Unions. Cheltenham, England, and Northampton, MA: Edward Elgar, 2003, pp. 118-171.

Neubäumer, Renate and Susanne Kohaut. "Unternehmen investieren nicht nur in Sachkapital." Zeitschrift für Betriebswirtschaft 72 (2002): 403-427.

Odgers, Cameron W. and Julian R. Betts. "Do Unions Reduce Investment? Evidence from Canada" Industrial and Labor Relations Review 51 (October 1997): 18-36.

Rubin, Don. "Estimating Causal Effects of Treatments in Randomized and Nonrandomized Studies." Journal of Educational Psychology 66 (1974): 688-701.

Schnabel, Claus and Joachim Wagner. "Industrial Relations and Trade Union Effects on Innovation in Germany”. Labour 8 (Autumn 1994): 489-503.

Van der Ploeg, Frederick. "Trade Unions and Investment: A Noncooperative Approach." European Economic Review 31 (October 1987): 1465-1492. 


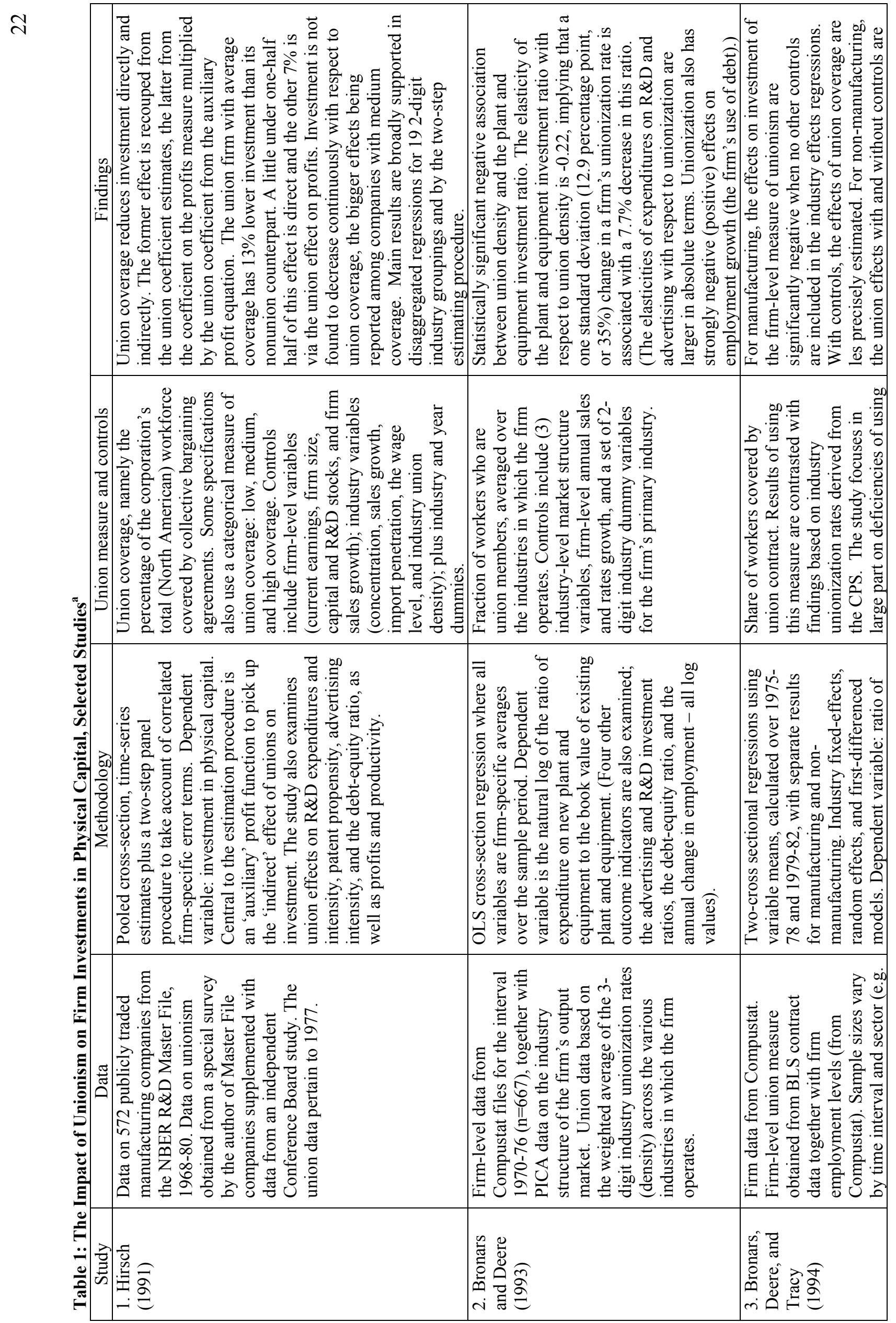




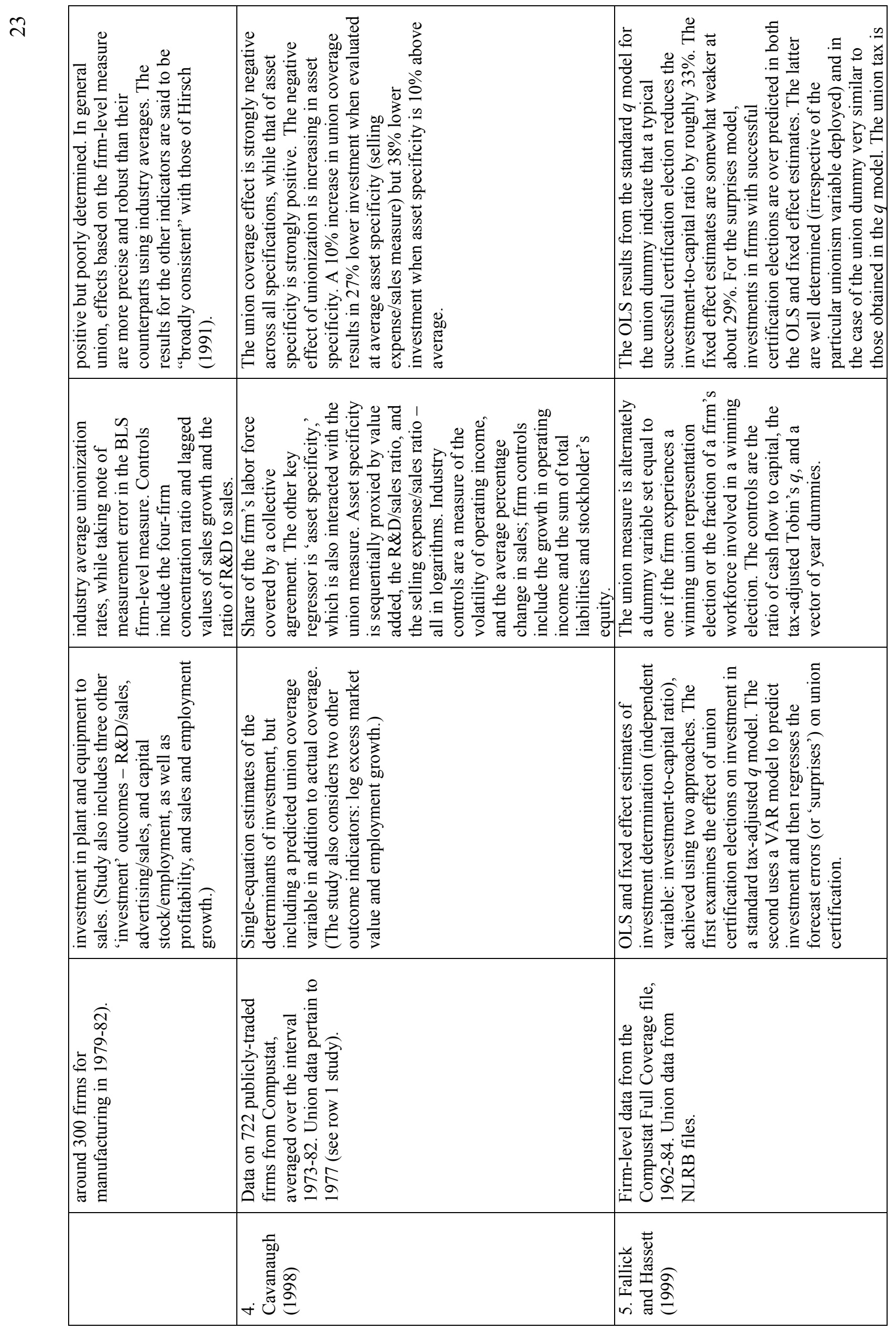




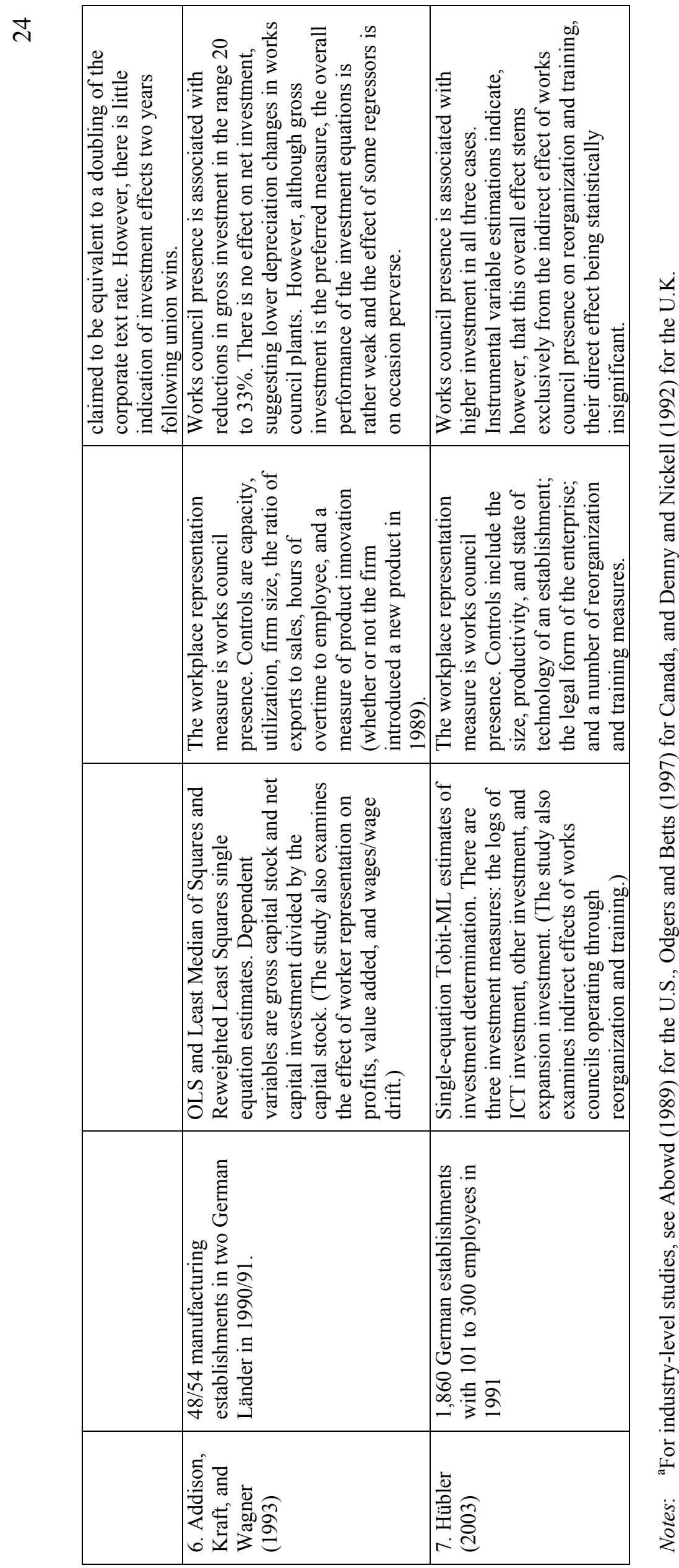


Table 2: OLS Regressions of Investment for all Plants

(Endogenous variable: investment divided by total sales, average of 2000-2002)

\begin{tabular}{|c|c|c|}
\hline Investment Measure & Total & Expansion \\
\hline \multicolumn{3}{|l|}{ Works council dummies: } \\
\hline $\begin{array}{l}\text { Works council never present } \\
\text { (1998: no; 2000: no; 2002: no) }\end{array}$ & Reference Group & Reference Group \\
\hline Works council formation & 0.013 & -0.001 \\
\hline (1998: no; 2000: yes; 2002: yes) & {$[0.74]$} & {$[0.08]$} \\
\hline Works council dissolution & -0.005 & -0.001 \\
\hline (1998: yes; 2000: no; 2002: no) & {$[1.02]$} & {$[0.11]$} \\
\hline Works council always present & 0.021 & 0.008 \\
\hline (1998: yes; 2000: yes; 2002: yes) & {$[2.90]^{* * *}$} & {$[1.74]^{*}$} \\
\hline \multirow[t]{2}{*}{ Sales growth (between 2000 and 2002) } & 0.009 & 0.010 \\
\hline & {$[1.71]^{*}$} & {$[2.53]^{* *}$} \\
\hline Profit situation of the establishment in 1999 & 0.011 & 0.007 \\
\hline (dummy: 1=good/very good) & {$[2.09] * *$} & {$[1.98] * *$} \\
\hline \multirow[t]{2}{*}{ Number of employees in 2000} & $4.23 e-06$ & $2.11 \mathrm{e}-06$ \\
\hline & {$[1.59]$} & {$[1.15]$} \\
\hline \multirow[t]{2}{*}{ Number of employees in 2000 squared } & $-9.44 \mathrm{e}-11$ & $-4.90 \mathrm{e}-11$ \\
\hline & {$[1.46]$} & {$[1.08]$} \\
\hline \multirow{2}{*}{\multicolumn{3}{|c|}{$\begin{array}{l}\text { Collective agreement in } 2000 \\
\text { (reference category: no collective agreement) }\end{array}$}} \\
\hline & & \\
\hline \multirow[t]{2}{*}{ - at sectoral level (dummy) } & 0.012 & 0.006 \\
\hline & {$[1.82]^{*}$} & {$[1.15]$} \\
\hline \multirow[t]{2}{*}{ - at firm level (dummy) } & -0.002 & 0.001 \\
\hline & {$[0.18]$} & {$[0.09]$} \\
\hline \multirow[t]{2}{*}{ Eastern Germany (dummy) } & 0.017 & 0.009 \\
\hline & {$[2.93]^{* * *}$} & {$[2.33]^{* *}$} \\
\hline Total investment divided by total sales & 0.303 & \\
\hline (average of 1997-1999) & {$[4.11]^{* * *}$} & \\
\hline \multirow{2}{*}{\multicolumn{2}{|c|}{$\begin{array}{l}\text { Expansion investment divided by total sales } \\
\text { (average of 1997-1999) }\end{array}$}} & 0.219 \\
\hline & & {$[2.81]^{* * *}$} \\
\hline \multirow[t]{2}{*}{10 industry dummies } & yes*** & yes*** \\
\hline & 0.073 & 0.044 \\
\hline Constant & {$[3.01]^{* * *}$} & {$[2.07]^{* *}$} \\
\hline Number of observations (n) & 2014 & 1945 \\
\hline Works council formation & 19 & 16 \\
\hline Works council never present & 1309 & 1277 \\
\hline Works council dissolution & 26 & 25 \\
\hline Works council always present & 660 & 627 \\
\hline $\mathrm{R}^{2}$ & 0.27 & 0.11 \\
\hline
\end{tabular}

Notes: Huber/White sandwich estimator is used to calculate the standard errors of the estimates. $|\mathrm{t}|$-statistics in brackets. $* * *, * *, *$ denote significance at the $.01, .05$, and .10 levels, respectively. 
Table 3: OLS Regressions of Investment for Groups of Plants with No Change in Works Council Regime (Endogenous variable: investment divided by total sales, average of 2000-2002)

\begin{tabular}{|c|c|c|c|c|}
\hline Works council regime & $\begin{array}{l}\text { Works cou } \\
\text { (1998: no; }\end{array}$ & $\begin{array}{l}\text { ver present } \\
\text { no; 2002: no) }\end{array}$ & $\begin{array}{l}\text { Works cou } \\
\text { (1998: yes }\end{array}$ & $\begin{array}{l}\text { ways present } \\
\text { yes; 2002: yes) }\end{array}$ \\
\hline Investment measure & Total & Expansion & Total & Expansion \\
\hline Sales growth (between 2000 and 2002) & $\begin{array}{l}0.007 \\
{[1.40]}\end{array}$ & $\begin{array}{l}0.009 \\
{[2.08]^{* *}}\end{array}$ & $\begin{array}{l}0.030 \\
{[1.29]}\end{array}$ & $\begin{array}{l}0.018 \\
{[1.20]}\end{array}$ \\
\hline Profit situation of the establishment in & 0.018 & 0.010 & $-2.3 e .04$ & 0.002 \\
\hline 1999 (dummy: 1=good/very good) & {$[2.66]^{* * *}$} & {$[2.16]^{* *}$} & {$[0.03]$} & {$[0.35]$} \\
\hline Number of employees in 2000 & $\begin{array}{l}-1.5 \mathrm{e}-05 \\
{[0.22]}\end{array}$ & $\begin{array}{l}-2.6 \mathrm{e}-05 \\
{[0.48]}\end{array}$ & $\begin{array}{l}5.40 \mathrm{e}-06 \\
{[2.08]^{* *}}\end{array}$ & $\begin{array}{l}3.20 \mathrm{e}-06 \\
{[1.62]}\end{array}$ \\
\hline Number of employees in 2000 squared & $\begin{array}{l}-5.29 \mathrm{e}-08 \\
{[0.70]}\end{array}$ & $\begin{array}{l}-2.36 \mathrm{e}-10 \\
{[0.00]}\end{array}$ & $\begin{array}{l}-1.18 \mathrm{e}-10 \\
{[1.80]^{*}}\end{array}$ & $\begin{array}{l}-7.19 \mathrm{e}-11 \\
{[1.50]}\end{array}$ \\
\hline $\begin{array}{l}\text { Collective agreement in } 2000 \\
\text { (reference: no collective agreement) }\end{array}$ & & & & \\
\hline - at sectoral level (dummy) & $\begin{array}{l}0.008 \\
{[0.96]}\end{array}$ & $\begin{array}{l}0.005 \\
{[0.80]}\end{array}$ & $\begin{array}{l}0.011 \\
{[0.87]}\end{array}$ & $\begin{array}{l}0.003 \\
{[0.55]}\end{array}$ \\
\hline - at firm level (dummy) & $\begin{array}{l}-0.003 \\
{[0.36]}\end{array}$ & $\begin{array}{l}1.8 \mathrm{e}-04 \\
{[0.04]}\end{array}$ & $\begin{array}{l}-0.019 \\
{[1.02]}\end{array}$ & $\begin{array}{l}-0.011 \\
{[0.96]}\end{array}$ \\
\hline Eastern Germany (dummy) & $\begin{array}{l}0.008 \\
{[1.27]}\end{array}$ & $\begin{array}{l}0.004 \\
{[0.85]}\end{array}$ & $\begin{array}{l}0.027 \\
{[2.16]^{* *}}\end{array}$ & $\begin{array}{l}0.020 \\
{[3.03]^{* *}}\end{array}$ \\
\hline $\begin{array}{l}\text { Total investment divided by total sales } \\
\text { (average of 1997-1999) }\end{array}$ & $\begin{array}{l}0.178 \\
{[2.35]^{* *}}\end{array}$ & & $\begin{array}{l}0.401 \\
{[3.42]^{* * *}}\end{array}$ & \\
\hline $\begin{array}{l}\text { Expansion investment divided by } \\
\text { total sales (average of 1997-1999) }\end{array}$ & & $\begin{array}{l}0.170 \\
{[1.78]^{*}}\end{array}$ & & $\begin{array}{l}0.286 \\
{[2.15]^{*}}\end{array}$ \\
\hline 10 industry dummies & yes*** & yes** & yes & yes \\
\hline Constant & $\begin{array}{l}0.104 \\
{[3.80]^{* * *}}\end{array}$ & $\begin{array}{l}0.055 \\
{[2.37]^{* *}}\end{array}$ & $\begin{array}{l}.006 \\
{[0.22]}\end{array}$ & $\begin{array}{l}-0.006 \\
{[0.49]}\end{array}$ \\
\hline Number of observations (n) & 1309 & 1277 & 660 & 627 \\
\hline $\mathrm{R}^{2}$ & 0.14 & 0.08 & 0.45 & 0.19 \\
\hline
\end{tabular}

Notes: Huber/White sandwich estimator is used to calculate the standard errors of the estimates. |t|-statistics in brackets. $* * *, * *, *$ denote significance at the $.01, .05$, and .10 levels, respectively. 
Table 4: Difference between Observed and Predicted Investment Divided by Total Sales, Average of 20002002

\begin{tabular}{|lrrrr|}
\hline Group & \multicolumn{2}{c}{$\begin{array}{l}\text { Works council formation } \\
\text { (1998: no; 2000: yes; 2002: yes) }\end{array}$} & \multicolumn{2}{c|}{$\begin{array}{c}\text { Works council dissolution } \\
\text { (1998: yes; 2000: no; 2002: no) }\end{array}$} \\
\hline Investment measure & \multicolumn{1}{c}{ Total } & Expansion & Total & Expansion \\
\hline $\mathrm{n}$ & 19 & 16 & 26 & 25 \\
Mean Observed & 0.073 & 0.035 & 0.036 & 0.017 \\
Mean Predicted & -0.047 & 0.022 & 0.055 & 0.024 \\
Mean Difference & 0.121 & 0.013 & -0.018 & -0.007 \\
t-statistic & -1.154 & -0.789 & $2.936^{* * *}$ & 1.217 \\
\hline
\end{tabular}

Note: Predictions on the basis of parameter estimates reported in Table 3. Estimates for plants which never (always) had a works council were used to predict the investment divided by total sales measure for plants setting up (abandoning) a works council. 
Table 5: Mean Values of Variables for Plants with Different Works Council Regimes, All Plants

\begin{tabular}{|c|c|c|c|c|c|c|}
\hline & (1) & (2) & & (3) & (4) & \\
\hline Works council regime & $\begin{array}{l}\text { Formation } \\
\text { (1998: no; } \\
\text { 2000: yes; } \\
\text { 2002: yes) }\end{array}$ & $\begin{array}{l}\text { Never present } \\
\text { (1998: no; } \\
\text { 2000: no; } \\
\text { 2002: no) }\end{array}$ & $\begin{array}{c}\text { P- } \\
\text { value }^{\text {a }}\end{array}$ & $\begin{array}{l}\text { Dissolution } \\
\text { (1998: yes; } \\
\text { 2000: no; } \\
\text { 2002: no) }\end{array}$ & $\begin{array}{l}\text { Always present } \\
\text { (1998: yes; } \\
\text { 2000: yes; } \\
\text { 2002: yes) }\end{array}$ & $\begin{array}{c}\mathrm{P}- \\
\text { value }^{\mathrm{a}}\end{array}$ \\
\hline $\mathrm{n}$ & 29 & 1656 & & 33 & 771 & \\
\hline \multicolumn{7}{|l|}{ Variable $^{\mathrm{b}}$} \\
\hline Number of employees & 304.1 & 27.71 & .20 & 50.52 & 631.1 & .00 \\
\hline Branch plant (dummy: $1=$ yes) & 0.345 & 0.057 & .00 & 0.152 & 0.292 & .04 \\
\hline $\begin{array}{l}\text { Economic performance } \\
\text { (dummy: 1=very good/good) }\end{array}$ & 0.552 & 0.377 & .08 & 0.182 & 0.358 & .02 \\
\hline Share of blue-collar workers & 0.596 & 0.653 & .36 & 0.728 & 0.609 & .03 \\
\hline Share of part-time employees & 0.128 & 0.154 & .50 & 0.055 & 0.087 & .11 \\
\hline Share of female employees & 0.292 & 0.365 & .12 & 0.299 & 0.297 & .97 \\
\hline Eastern Germany (dummy) & 0.379 & 0.603 & .02 & 0.697 & 0.405 & .00 \\
\hline \multicolumn{7}{|l|}{ Collective agreement } \\
\hline - at sectoral level $(1=$ yes $)$ & 0.690 & 0.399 & .00 & 0.515 & 0.767 & .01 \\
\hline - at firm level $(1=$ yes $)$ & 0.138 & 0.061 & .25 & 0.030 & 0.149 & .00 \\
\hline $\begin{array}{l}\text { Establishment formation in the } \\
\text { last five years }(1=\text { yes })\end{array}$ & 0.241 & 0.337 & .25 & 0.182 & 0.154 & .69 \\
\hline $\begin{array}{l}\text { Legal form of firm (dummy: } \\
1 \text { = family-owned firm) }\end{array}$ & 0.069 & 0.553 & .00 & 0.242 & 0.125 & .13 \\
\hline $\begin{array}{l}\text { Total investment divided by total } \\
\text { sales (average of } 2000-2002 \text { ) }\end{array}$ & 0.065 & 0.047 & .23 & 0.031 & 0.081 & .00 \\
\hline $\begin{array}{l}\text { Expansion investment divided by } \\
\text { total sales (average of } 2000-2002)^{c}\end{array}$ & 0.027 & 0.019 & .41 & 0.014 & 0.032 & .02 \\
\hline
\end{tabular}

Notes: ${ }^{\text {a }}$ Two-sample t-test with unequal variance of the hypothesis that difference in the means between (1) and (2) (respectively (3) and (4)) is zero.

${ }^{\mathrm{b}}$ Unless otherwise stated, information refers to the year 1998.

${ }^{c}$ Number of observations for groups (1), (2), (3) and (4) is 28, 1634, 32 and 760, respectively. 
Table 6: Mean Values of Variables for Plants with Different Works Council Regimes, Matched Plants

\begin{tabular}{|c|c|c|c|c|c|c|}
\hline & (1) & (2) & & (3) & (4) & \\
\hline Works council regime & $\begin{array}{l}\text { Formation } \\
\text { (1998: no; } \\
\text { 2000: yes; } \\
\text { 2002: yes) }\end{array}$ & $\begin{array}{l}\text { Never present } \\
\text { (1998: no; } \\
\text { 2000: no; } \\
\text { 2002: no) }\end{array}$ & $\begin{array}{c}\mathrm{P}- \\
\text { value }^{\mathrm{a}}\end{array}$ & $\begin{array}{c}\text { Dissolution } \\
\text { (1998: yes; } \\
\text { 2000: no; 2002: } \\
\text { no) }\end{array}$ & $\begin{array}{l}\text { Always present } \\
\text { (1998: yes; } \\
\text { 2000: yes; } \\
\text { 2002: yes) }\end{array}$ & $\begin{array}{c}\text { P- } \\
\text { value }^{a}\end{array}$ \\
\hline $\mathrm{n}$ & 25 & 25 & & 21 & 21 & \\
\hline \multicolumn{7}{|l|}{ Variable $^{\mathrm{b}}$} \\
\hline Number of employees & 97.68 & 91.48 & .89 & 67.19 & 70.48 & .85 \\
\hline Branch plant (dummy: $1=$ yes) & 0.280 & 0.320 & .76 & 0.095 & 0.143 & .64 \\
\hline $\begin{array}{l}\text { Economic performance } \\
\text { (dummy: } 1=\text { very good/good) }\end{array}$ & 0.520 & 0.440 & .58 & 0.190 & 0.095 & .39 \\
\hline Share of blue-collar workers & 0.589 & 0.569 & .84 & 0.704 & 0.705 & 1.0 \\
\hline Share of part-time employees & 0.141 & 0.138 & .96 & 0.053 & 0.093 & .46 \\
\hline Share of female employees & 0.299 & 0.353 & .48 & 0.263 & 0.295 & .66 \\
\hline Eastern Germany (dummy) & 0.440 & 0.440 & 1.0 & 0.619 & 0.619 & 1.0 \\
\hline \multicolumn{7}{|l|}{ Collective agreement } \\
\hline - at sectoral level $(1=$ yes $)$ & 0.680 & 0.800 & .34 & 0.571 & 0.619 & .76 \\
\hline - at firm level $(1=$ yes $)$ & 0.120 & 0.040 & .31 & 0.048 & 0.000 & .33 \\
\hline $\begin{array}{l}\text { Establishment formation in the } \\
\text { last five years }(1=\text { yes })\end{array}$ & 0.240 & 0.280 & .75 & 0.095 & 0.381 & .03 \\
\hline $\begin{array}{l}\text { Legal form of firm (dummy: } \\
1 \text { = family-owned firm) }\end{array}$ & 0.080 & 0.040 & .56 & 0.238 & 0.143 & .44 \\
\hline
\end{tabular}

Notes: ${ }^{a}$ Two-sample t-test with unequal variance of the hypothesis that difference in the means between (1) and (2) (respectively (3) and (4)) is zero.

${ }^{\mathrm{b}}$ Information refers to the year 1998 . 
Table 7: Mean Values of Investment for Plants with Different Works Council Regimes. Matched Plants

\begin{tabular}{|c|c|c|c|c|c|c|}
\hline & (1) & (2) & & (3) & (4) & \\
\hline Works council regime & $\begin{array}{l}\text { Formation } \\
\text { (1998: no; } \\
\text { 2000: yes; } \\
\text { 2002: yes) }\end{array}$ & $\begin{array}{l}\text { Never present } \\
\text { (1998: no; } \\
\text { 2000: no; } \\
\text { 2002: no) }\end{array}$ & $\begin{array}{c}\text { P- } \\
\text { value }^{\text {a }}\end{array}$ & $\begin{array}{l}\text { Dissolution } \\
\text { (1998: yes; } \\
\text { 2000: no; } \\
\text { 2002: no) }\end{array}$ & $\begin{array}{l}\text { Always present } \\
\text { (1998: yes; } \\
\text { 2000: yes; } \\
\text { 2002: yes) }\end{array}$ & $\begin{array}{c}\mathrm{P}- \\
\text { value }^{\mathrm{a}}\end{array}$ \\
\hline \multicolumn{7}{|l|}{ Variable } \\
\hline $\begin{array}{l}\text { Total investment divided by total } \\
\text { sales (average of 2000-2002) }\end{array}$ & 0.060 & 0.042 & .30 & 0.044 & 0.043 & .96 \\
\hline $\mathrm{n}$ & 25 & 25 & & 21 & 21 & \\
\hline \multirow{2}{*}{$\begin{array}{l}\text { Expansion investment divided by } \\
\text { total sales (average of 2000-2002) } \\
n\end{array}$} & 0.020 & 0.018 & \multirow[t]{2}{*}{.80} & 0.020 & 0.019 & \multirow[t]{2}{*}{.93} \\
\hline & 24 & 24 & & 20 & 20 & \\
\hline
\end{tabular}

Notes: ${ }^{\text {a }}$ Two-sample t-test with unequal variance of the hypothesis that difference in the means between (1) and (2) (respectively (3) and (4)) is zero. 